\title{
Flavonoids from Macaranga lowii
}

\author{
Widiastuti Agustina, Lia D. Juliawaty, Euis H. Hakim \& Yana M. Syah ${ }^{1}$
}

Organic Chemistry Division, Faculty of Mathematics and Natural Sciences, Institut Teknologi Bandung, Jalan Ganesha 10, Bandung 40132, Indonesia

${ }^{1}$ E-mail: yana@chem.itb.ac.id

\begin{abstract}
A new isoprenylated dihydroflavonol derivative, macalowiinin (1), together with two known flavonoids 4'-O-methyl-8-isoprenylnaringenin (2) and 4'-O-methyl-5,7,4'-trihydroxyflavone (3) (= acasetin), have been isolated from the methanol extract of the leaves of Macaranga lowii. The structures of these compounds were determined based on UV, NMR, and mass spectral data, and optical rotation. Preliminary cytotoxic evaluation of compounds $\mathbf{1}-\mathbf{3}$ against P388 cells showed that compound 3 is the most active with $\mathrm{IC}_{50}$ was $58.7 \mu \mathrm{M}$.
\end{abstract}

Keywords: acasetin; cytotoxicity; isoprenylated dihydroflavonol; macaranga lowii; macalowiniin; 4'-O-methyl-8-isoprenylnaringenin; P-388 cells.

\section{Introduction}

Macaranga is a large genus of Euphorbiaceae consisting of about 250 species and is distributed in the tropical region of the world, including Indonesia [1,2]. Phytochemical investigation has revealed that this genus is a rich source of phenolic compounds, particularly the isoprenylated and geranylated flavonoids and stilbenes [1,3]. In the course of our phytochemical study on Indonesian Macaranga, recently we reported the isolation of isoprenylated flavanones and dihydrochalcones from $M$. trichocarpa [4], isoprenylated, geranylated and farnesylated flavonols from $M$. rhizinoides [5], M. pruinosa [6], and $M$. gigantea [7], respectively, and a unique stilbene and dihydroflavonol derivatives containing an irregular sesquiterpenyl side chain from M. pruinosa [6]. As part of this study, we have also examined a species collected from Kalimantan island of Indonesia, M. lowii King ex. Hook.f., and successfully isolated three flavonoids, including a new isoprenylated dihidroflavonol derivative, named macalowiinin (1), together with two known flavonoids 4'- $O$ methyl-8-isoprenylnaringenin (2) [8] and 4'-O-methyl-5,7,4'-trihydroxyflavone (3) (= acasetin) [9] (Figure 1), from the methanol extracts of the leaves of the plant. This paper reports the isolation and structure elucidation of the new compound and cytoxic properties of compounds $\mathbf{1}$ - $\mathbf{3}$ against murine leukemia P-388 cells. 


\section{Results and Discussion}

Macalowiinin (1) was isolated as an optically active pale yellow powder, and its UV spectrum exhibited absorption maxima $(296,334$ [sh] nm) typical for a dihydroflavonol [6]. The UV absorption showed a bathochromic shift $(37 \mathrm{~nm})$ on addition $\mathrm{NaOH}$ solution, indicating that the compound contains one or more free $-\mathrm{OH}$ phenolic groups. More spesifically, the presence of a free $-\mathrm{OH}$ phenolic group at C-5 was also disclosed from the observation of a large bathochromic shift (22 and $60 \mathrm{~nm}$ ) on addition $\mathrm{AlCl} 3$ solution. However, on addition of $\mathrm{HCl}$, following $\mathrm{AlCl} 3$ addition, the $\mathrm{UV}$ spectrum was unchanged indicating that the compound does not bear an 1,2-dihydroxyl group in the aromatic rings. The HR-ESI-MS spectrum (negative mode) of 1 showed a quasimolecular $[\mathrm{M}-\mathrm{H}]$ - ion $(\mathrm{m} / \mathrm{z}$ 369.1340) consistent with a molecular formula $\mathrm{C} 21 \mathrm{H} 22 \mathrm{O} 6$ (calculated $[\mathrm{M}-\mathrm{H}]-369.1338, \Delta 0.5 \mathrm{ppm}$ ), suggesting that 1 is a 2,3dihydroflavonol derivative containing an isoprenyl and a methoxyl groups. In the $1 \mathrm{H}$ NMR spectrum (Tab. 1.) the presence of three proton signals at $\delta \mathrm{H} 5.09$, 4.73, and 4.61, with multiplicities $\mathrm{d}(\mathrm{J}=11.5 \mathrm{~Hz}), \mathrm{d}(\mathrm{J}=4.0 \mathrm{~Hz})$, and $\mathrm{dd}(\mathrm{J}=$ $11.5,4.0 \mathrm{~Hz}$ ), respectively, confirmed for the 2,3-dihydroflavonol skeleton in 1 . The $1 \mathrm{H}$ NMR spectrum of 1 also showed signals for an isoprenyl $(\delta \mathrm{H} 5.16,1 \mathrm{H}$; $3.19,2 \mathrm{H} ; 1.59$ and 1.54 , each $3 \mathrm{H})$ and a methoxyl $(\delta \mathrm{H} 3.82,3 \mathrm{H})$ groups, and a proton singlet signal at $\delta \mathrm{H} 11.64$ that is consistent with an $\mathrm{OH}$-phenolic at C-5. Further analysis of the $1 \mathrm{H}$ spectrum in the aromatic region revealed the presence of a pair of doublets of two-proton signals ( $\delta \mathrm{H} 7.52$ and 6.99) and a singlet of one-proton signal ( $\delta \mathrm{H} 6.06)$, suggesting that the isoprenyl group is either at C-6 or C-8. By analysis of HMQC and HMBC spectra of 1, the 5-OH phenolic signal $(\delta \mathrm{H} 11.64)$ exhibited $1 \mathrm{H}-13 \mathrm{C}$ long range correlations with the signals of two aromatic quarternary $(\delta \mathrm{C} 162.6, \mathrm{C}-5 ; 101.5, \mathrm{C}-4 \mathrm{a})$ and an aromatic methine ( $\delta \mathrm{C} 96.6, \mathrm{C}-6)$ carbon atoms, and consequently these correlations assign the isoprenyl group at C-8. Furthermore, the methoxyl proton signal $(\delta \mathrm{H} 3.82)$ displayed a long range correlation with an oxyaryl carbon signal ( $\delta \mathrm{C} 160.8, \mathrm{C}-4$ ') that does not have a correlation to the methylene proton signal $(\delta \mathrm{H} 3.19)$ of an isoprenyl group, confirming that the methoxyl group is at C-4'. From these NMR data analysis, macalowiinin (1) was assigned as 4'-O-methyl-5,7,4'-trihydroxy-8-isoprenyl-2,3-dihydroflavonol. Other HMQC and HMBC correlations, as well as 13C NMR data assignment, that are consistent with the structure 1 are shown in Tab. 1. The absolute stereochemistry at C-2/C-3 was determined as shown in the structure 1 , based on the coupling constant $(\mathrm{J}=11.5 \mathrm{~Hz}$, trans $)$ between $\mathrm{H}-2 / \mathrm{H}-3$ and the optical rotation $\left(+5.5^{\circ}\right)[1]$. 
<smiles>COc1ccc([C@@H]2Oc3c([CH+]C=C(C)F)c(O)cc(O)c3C(=O)[C@H]2O)cc1</smiles>

1<smiles>COc1ccc([C@@H]2CC(=O)c3c(O)cc(O)c(CC=C(C)C)c3O2)cc1</smiles>

2<smiles>COc1ccc(-c2cc(=O)c3c(O)cc(O)cc3o2)cc1</smiles>

3

Figure 1 Structures of the flavonoids from M. lowii.

The occurrence of dihydroflavonol and flavone derivatives in the genus Macaranga is very limited. To our knowledge the dihydroflavonol derivatives have been isolated and identified only in three species, M. alnifolia [1], M. conifera [10], and M. pruinosa [6], while the presence of the flavone is the second time after a similar compound has been isolated from M. gigantea [7].

Table 1 NMR $\left({ }^{1} \mathrm{H}, 500 \mathrm{MHz} ;{ }^{13} \mathrm{C} 125 \mathrm{MHz}\right)$ data of macalowiinin (1).

\begin{tabular}{|c|c|c|c|}
\hline No C & $\delta_{\mathrm{H}}$ & $\delta_{\mathrm{C}}$ & HMBC $\left({ }^{1} \mathrm{H} \Leftrightarrow{ }^{13} \mathrm{C}\right)$ \\
\hline 2 & $5,09(\mathrm{~d}, 11,5)$ & 84,0 & $\mathrm{C}-3, \mathrm{C}-4, \mathrm{C}-1^{\prime}, \mathrm{C}-2^{\prime} / \mathrm{C}-6^{\prime}$ \\
\hline 3 & $4,61(\mathrm{dd}, 11,5,4,0)$ & 73,2 & $\mathrm{C}-2, \mathrm{C}-4, \mathrm{C}-1^{\prime}$, \\
\hline $3-\mathrm{OH}$ & $4,73(\mathrm{~d}, 4,0)$ & - & - \\
\hline 4 & - & 198,4 & - \\
\hline $4 a$ & - & 101,5 & - \\
\hline 5 & - & 162,6 & - \\
\hline 6 & $6,06(s)$ & 96,6 & $\mathrm{C}-4 \mathrm{a}, \mathrm{C}-5, \mathrm{C}-7, \mathrm{C}-8$ \\
\hline 7 & - & 165,4 & - \\
\hline 8 & - & 108,6 & - \\
\hline $8 \mathrm{a}$ & - & 160,9 & - \\
\hline $1^{\prime}$ & - & 131,3 & - \\
\hline $2^{\prime} / 6^{\prime}$ & $7,52(\mathrm{~d}, 9,0)$ & 130,0 & $\mathrm{C}-2, \mathrm{C}-3^{\prime} / 5^{\prime}, \mathrm{C}-4^{\prime}, \mathrm{C}-6^{\prime} / 2^{\prime}$ \\
\hline $3^{\prime} / 5$ & $6,99(\mathrm{~d}, 9,0)$ & 114,4 & $\mathrm{C}-1^{\prime}, \mathrm{C}-2^{\prime} / 6^{\prime}, \mathrm{C}-4^{\prime}, \mathrm{C}-5^{\prime} / 3^{\prime}$ \\
\hline $4^{\prime}$ & - & 160,8 & - \\
\hline $1 "$ & $3,19(\mathrm{~d}, 7,5)$ & 22,0 & C-7, C-8, C-8a, C-2", C-3" \\
\hline $2 "$ & $5,16(\mathrm{tm}, 7,5)$ & 123,3 & C-1", C-4", C-5" \\
\hline $3 "$ & - & 130,5 & - \\
\hline $4 "$ & $1,59(\mathrm{~s})$ & 25,8 & C-2", C-3", C-5" \\
\hline $5^{\prime \prime}$ & $1,54(\mathrm{~s})$ & 17,8 & C-2", C-3", C-4" \\
\hline $5-\mathrm{OH}$ & $11,64(\mathrm{~s})$ & - & C-4a, C-5, C-6 \\
\hline $4^{\prime}-\mathrm{OCH}_{3}$ & $3,82(\mathrm{~s})$ & 55,5 & C-4' \\
\hline
\end{tabular}


Thus, the presence of these flavonoids could have a significant as a marker of a certain group of Macaranga.

Compounds $1-3$ were evaluated for their cytotoxicities against murine leukemia P-388 cells, showing their $\mathrm{IC}_{50}$ were $119.3,166.6$, and $58.7 \mu \mathrm{M}$, respectively.

\section{$3 \quad$ Experimental}

\subsection{General}

Optical rotation was measured with Polarimeter Perkin Elmer 341, while UV spectra were acquired with Varian 100 Conc spectrometer. ${ }^{1} \mathrm{H}$ and ${ }^{13} \mathrm{C}$ NMR spectra were recorded with a Bruker Avance 500 spectrometer $\left({ }^{1} \mathrm{H}, 500 \mathrm{MHz}\right.$; ${ }^{13} \mathrm{C}, 125 \mathrm{MHz}$ ), and mass spectra were measured with an ESI-TOF Water LCT Premier XE (negative mode). VLC (vacuum liquid chromatography) and PCC (planar centrifugal chromatography) were carried out using Merck silica gel 60 $\mathrm{GF}_{254}$, respectively, and for TLC analysis, pre-coated silica gel plates (Merck Kieselgel $60 \mathrm{GF}_{254}, 0.25 \mathrm{~mm}$ thickness) were used. Solvents used for extraction and preparative chromatography are technical grades that were distilled before use.

\subsection{Plant Materials}

The leaves of $M$. lowii were collected from Kalimantan island, Indonesia, in August 2008. The plant was identified by Mr. Ismail, Herbarium Bogoriense, Bogor, Indonesia, and the voucher specimen was deposited in the herbarium.

\subsection{Extraction and Isolation}

The powdered and dried leaves of $M$. lowii $(0.8 \mathrm{~kg})$ were macerated in methanol at room temperature $(3 \times 5 \mathrm{~L})$, and after evaporation of the solvent gave a methanol extract as a semisolid residue $(130 \mathrm{~g})$. A portion of the extract $(50 \mathrm{~g})$ was divided into acetone-soluble $(22 \mathrm{~g})$ and acetone-insoluble $(28 \mathrm{~g})$ fractions. The acetone soluble fraction was fractionated through a VLC column, eluted with $n$-hexane-EtOAc $(17: 3,4: 1,7: 3$, and $1: 1$, each $450,300,300$, and $600 \mathrm{~mL}$, respectively) to give ten fractions A-J. TLC analysis, monitored with UV lamp $254 \mathrm{~nm}$, showed that the suspected flavonoid spots were contained in the fraction D and $\mathrm{H}$. Refractionation of the fraction D (1.08 g) by using the same method (19:1, 9:1, 17:3, and 4:1, each 150, 150, 200, and $200 \mathrm{~mL}$, respectively) afforded 14 fractions, and the fractions rich with flavonoids $(175 \mathrm{mg})$ were purified with sephadex LH-20 column eluted with $\mathrm{MeOH}$ to give a fraction which on crystallization yielded compound $2(50 \mathrm{mg})$ [8]. Fraction H $(720 \mathrm{mg})$ 
was also refractionated using PCC eluted with $n$-hexane-EtOAc ( $4: 1$ to $3: 2)$ to give two major fraction $\mathrm{H} 1$ and $\mathrm{H} 2$ containing flavonoids. Purification of fraction $\mathrm{H} 1(140 \mathrm{mg})$ using the same method ( $n$-hexane-EtOAc, 4:1) afforded compound $1(25 \mathrm{mg})$. Fraction H2 $(215 \mathrm{mg})$ was purified using PCC technique ( $n$-hexane-EtOAc, 9:1) and sephadex LH-20 (MeOH) to give compound 3 (5 $\mathrm{mg}$ ) [9].

\section{Macalowiinin (1)}

Pale yellow powders; $[\alpha]_{\mathrm{D}}=+5.5^{\circ}(c 0.15, \mathrm{MeOH}) ; \mathrm{UV}(\mathrm{MeOH}) \lambda_{\max } \mathrm{nm}: 296$, 334 (sh); UV (MeOH+NaOH) $\lambda_{\max } \mathrm{nm}: 333$; UV $\left(\mathrm{MeOH}+\mathrm{AlCl}_{3}\right) \lambda_{\max } \mathrm{nm}: 318$, 394 (sh); UV (MeOH+AlCl $\left.{ }_{3}+\mathrm{HCl}\right) \lambda_{\max }$ nm: 318,394 (sh); ${ }^{1} \mathrm{H}$ NMR $(500 \mathrm{MHz}$, acetone- $\left.d_{6}\right) \delta$ ppm: see Tab. $1 . ;{ }^{13} \mathrm{C}$ NMR $\left(125 \mathrm{MHz}\right.$, acetone- $\left.d_{6}\right) \delta$ ppm: see Table 1.; HR-ESI-MS m/z: [M-H] 369.1340 (calculated [M-H] for $\mathrm{C}_{21} \mathrm{H}_{22} \mathrm{O}_{6}$ 369.1338).

\subsection{Cytotoxic Assay}

The cytotoxic properties of compounds $\mathbf{1}-\mathbf{3}$ were evaluated against murine leukemia P-388 cells, and were carried out by MTT assay according to the method previously described [11].

\section{Acknowledgement}

The authors are grateful for the financial support from Hibah Pasca Grant VII 2009, Contract No. 0052f/K01.20/SPK-LPPM///2009. We also thank Prof. Peter Proksch, the University of Dusseldorf, Germany, for NMR spectra measurements.

\section{References}

[1] Yoder, B.J., Cao, S., Norris, A., Miller, J.S., Ratovoson, F., Razafitsalama, J., Andriantsiferana, R., Rasamison, V.E. \& Kingston D.G.I., Antiproliferative Prenylated Stilbenes and Flavonoids from Macaranga Alnifolia from the Madagascar Rainforest, J. Nat. Prod., 25, 342-346, 2007.

[2] Airy Shaw, H.K., The Euphorbiaceae of Central Malesia (Celebes, Moluccas, Lesser Sunda Is.), Kew Bull., 37, 1-40, 1982.

[3] Kawakami, S., Harinantenaina, L., Matsunami, K., Otsuka, H., Shinzato, T. \& Takeda Y., Macaflavanones A-G, Prenylated Flavanones from the Leaves of Macaranga Tanarius, J. Nat.Prod., 71, 1872-1876, 2008.

[4] Syah, Y.M., Hakim, E.H., Achmad, S.A., Hanafi, M. \& Ghisalberti, E.L., Isoprenylated Flavanones and Dihydrochalcones from Macaranga Trichocarpa, Nat. Prod. Commun., 4, 63-67, 2009. 
[5] Tanjung, M., Mujahidin, D., Hakim, E.H., Darmawan, A. \& Syah, Y.M., Geranylated Flavonols from Macaranga Rhizinoides, Nat. Prod. Commun., 5, 1209-1211, 2010.

[6] Syah, Y.M. \& Ghisalberti, E.L., Phenolic Derivatives with an Irregular Sesquiterpenyl Side Chain from Macaranga Pruinosa, Nat. Prod. Commun., 5, 219-222, 2010.

[7] Tanjung, M., Hakim, E.H., Mujahidin, D., Hanafi, M., Syah, Y.M., Macagigantin, A Farnesylated Flavonol from Macaranga Gigantea, J. Asian Nat. Prod. Res., 11, 929-932, 2009.

[8] Parson, I.C., Gray, A.I. \& Waterman, P.G., New Triterpenes and Flavonoids from The Leaves of Basistoa Brasii, J. Nat. Prod., 56, 46-53, 1993.

[9] Fujinori. H. \& Neil, T.G.H., Flavones from Alnus rubra Bong. Coat Seed, Bull. FFPRI., 2, 85-91, 2003.

[10] Jang, D.S., Cuendet, M., Hawthorne, M.E., Kardono, L.B.S., Kawanishi, K., Fong, H.H.S., Mehta, R.G., Pezzuto, J.M. \& Kinghorn, A.D., Prenylated Flavonoids of The Leaves of Macaranga Conifera with Inhibitory Activity Against Cyclooxygenase-2, Phytochemistry, 61, 867872, 2002.

[11] Sahidin, Hakim, E.H., Juliawaty, L.D., Syah, Y.M., Din, L.B., Ghisalberti, E.L., Latip, J., Said, I.M. \& Achmad, S.A., Cytotoxic Properties of Oligostilbenoids from The Tree Bark of Hopea Dryobalanoides, Z. Naturforsch. C., 60, 723-727, 2005. 